\title{
Effects of a long-lasting hyperinsulinemia induced by insulin infusion on the subcellular distribution of liver insulin receptors in the rat
}

\author{
S. López ${ }^{1}$, B. Desbuquois ${ }^{1}$, C. Achagiotis ${ }^{2}$ and C. Benelli 1 \\ 1 INSERM U30, hôpital des Enfants-Malades, 75743 Paris Cedex 15; \\ 2 Collège de France, laboratoire de neurobiologie de la nutrition, rue des Ecoles, 75005 Paris, \\ France
}

(14th meeting of the INRA Development Group, Clermont-Ferrand, 25-27 May 1988)

\begin{abstract}
Summary - Acute hyperinsulinemias in rats have been shown to cause enhanced endocytosis of liver insulin receptors with little or no change in the total receptor number. To determine whether a similar phenomenon occurs in long-lasting hyperinsulinemias, the subcellular distribution of liver insulin receptors has been studied in rats infused continuously with insulin $(0.4$ and $0.2 \mathrm{U} / \mathrm{h})$ for 4 days. In rats in which plasma insulin concentration was maintained at $15-20 \mathrm{ng} / \mathrm{ml}$, there was, from 3 to $24 \mathrm{~h}$, a 2-fold decrease in insulin binding to plasma membranes (PM), along with 2 to 4 -fold increase in insulin binding to the light (GEI), intermediate (GEi) and heavy (GEh) Golgi-endosomal fractions; concomitantly, there was a 10-fold increase in the insulin content of Golgi-endosomal fractions. After $24 \mathrm{~h}$, the changes in insulin binding to PM and GEI were maintained, but the increase in both insulin binding activity and insulin content of GEi and GEh became progressively less marked, although plasma insulin concentration remained elevated. Throughout infusion, insulin binding to the total particulate fraction was unchanged. In rats, in which plasma insulin was maintained at $6-8 \mathrm{ng} /$ $\mathrm{ml}$, insulin binding to PM was decreased to a lesser degree and insulin binding to Golgi-endosomal fractions was unchanged (GEh) or decreased (GEI and GEi), although the insulin content of these fractions remained high. These results suggest that, while an enhanced receptor endocytosis accounts for the decrease in cell surface receptors observed at an early stage of the hyperinsulinemia, additional regulatory mechanisms are probably involved at a later stage.
\end{abstract}

insulin receptor - subcellular fraction - long-lasting hyperinsulinemia — rat liver

Résumé - Effets d'une hyperinsulinémie prolongée induite par une perfusion d'insuline sur la distribution subcellulaire des récepteurs hépatiques de l'insuline chez le rat. II a été établi antérieurement que des états d'hyperinsulinémie aigüe chez le rat induisaient une endocytose des récepteurs hépatiques de linsuline, mais ne modifiaient pas leur nombre total. Afin de déterminer si le même phénomène se produit au cours d'hyperinsulinémies de longue durée, la distribution subcellulaire des récepteurs de l'insuline a été étudiée chez des rats recevant une perfusion continue d'insuline $(0,4$ et $0,2 \mathrm{U} / \mathrm{h})$ pendant $4 j$. Chez les animaux dont l'insulinémie est maintenue à 15-20 $\mathrm{ng} / \mathrm{ml}$, on observe, de 3 à $24 \mathrm{~h}$, une diminution (2 fois) de la liaison de linsuline aux membranes plasmiques (PM) et, inversement, une augmentation (2-4 fois) de cette liaison aux fractions Golgiendosomales légères (GEl), intermédiaire (GEi) et lourde (GEh); simultanément, la teneur en insuline de GEi et GEh augmente d'environ 10 fois. Après $24 \mathrm{~h}$, les modifications de la liaison de l'insuline à PM et GEI restent inchangées, mais l'augmentation de l'activité de liaison et de la teneur en insuline de GEi et GEh s'atténue progressivement, malgré la persistance de l'hyperinsulinémie. Pendant toute la durée de la perfusion, la liaison de linsuline à la fraction particulaire totale reste inchangée. Chez les rats dont linsulinémie est maintenue à 6-8 $\mathrm{ng} / \mathrm{ml}$, la liaison de l'insuline à PM est diminuée à un degré moindre, et sa liaison aux fractions Golgi-endosomales est inchangée (GEh) ou diminuée (GEI et GEi), alors que la teneur en insuline de ces fractions reste élevée. Ces résultats 
suggèrent que, si une endocytose accrue des récepteurs rend compte de leur disparition de la surface cellulaire à un stade précoce de l'hyperinsulinémie, d'autres mécanismes de régulation sont probablement impliqués à un stade plus tardif.

récepteur de l'insuline - fraction subcellulaire — hyperinsulinémie de longue durée - fole de rat

\section{INTRODUCTION}

A decrease in the number of insulin receptors in liver plasma membranes has been observed in a number of rodent models in which plasma insulin concentration is elevated, either acutely, such as after injection of insulin (Desbuquois et al., 1982; Pezzino et al., 1980) and stimulants of insulin secretion (López \& Desbuquois, 1983), or chronically, such as in genetic (Clark \& Clark, 1982; Kahn et al., 1973; Posner et al., 1978) and acquired (Le Marchand et al., 1978) forms of obesity, or after iterative insulin injections (Vigneri et al., 1978). In acute hyperinsulinemia, the decrease in the number of insulin receptors in plasma membrane fractions is accompanied by a correlative increase in the number of receptors in Golgi-endosomal fractions, total receptor number remaining unaffected (Desbuquois et al., 1982; López \& Desbuquois, 1983). An additional finding in these models is an increase in the concentration of insulin in Golgiendosomal fractions. These findings have led to the suggestion that in acute hyperinsulinemia, enhanced receptor endocytosis is one major mechanism involved in the regulation of cell surface receptors.

We have recently presented evidence that in genetically obese Zucker rats, enhanced receptor endocytosis does not account for the loss of cell surface receptors observed in this animal model (López et al., 1988). To assess the involvement of receptor endocytosis in a nongenetic, long-lasting hyperinsulinemia, we have studied the subcellular distribution of he- patic insulin receptors in rats receiving a continuous infusion of insulin for 4 days. Our results suggest that only at an early stage of the hyperinsulinemia does enhanced receptor endocytosis account for the decrease in the number of cell surface receptors observed in this model.

\section{MATERIALS AND METHODS}

Male Wistar rats, weighing $180-220 \mathrm{~g}$, were infused with physiological saline $(0.375 \mathrm{ml} / \mathrm{h})$ or insulin (Actrapid, Novo, Copenhagen) diluted in saline for $3 \mathrm{~h}$ to 4 days through chronicallyimplanted intracardiac catheters as described by Benelli et al. (1988). To avoid insulin inactivation, all solutions used for infusion were freshly prepared each day. The rate of insulin infusion was generally $0.4 \mathrm{U} / \mathrm{h}$, less frequently $0.2 \mathrm{U} / \mathrm{h}$. At the time scheduled for study, the animals were sacrificed and the liver was removed and immediately homogenized.

A total particulate fraction, a plasma membrane fraction (PM), and light (GEI), intermediate (GEi) and heavy (GEh) Golgi-endosomal fractions were prepared from homogenates according to modifications (López \& Desbuquois, 1983,1987 ) or earlier described procedures. Subcellular fractions were stored in liquid nitrogen and assayed for protein, insulin binding activity and extractable insulin content as described by López and Desbuquois $(1983,1987)$.

Plasma insulin was determined by radioimmunoassay as described by López and Desbuquois (1983).

Statistical comparisons between salineinfused and insulin-infused rats were performed using Student's t-test, with values of insulin binding activities converted to percentages of the mean value observed in the control group. 


\section{RESULTS}

Specific activities of galactosyltransferase (a Golgi marker) in Golgi-endosomal fractions and of 5'-nucleotidase (a plasma membrane marker) in plasma membranes of saline-infused rats were similar to those reported previously in this laboratory, but the protein yield of Golgi-endosomal fractions was consistently lower (results not shown). Specific activities of marker enzymes and protein yield in subcellular fractions of insulin-infused rats did not differ from those of saline-injected controls.

Infusion of insulin at the rate of $0.4 \mathrm{U} / \mathrm{h}$ for 4 days caused a 6 to 8 -fold increase in plasma insulin concentration. The latter was detectable at $3 \mathrm{~h}$ and was maintained throughout the time of study (Fig. 1, upper panel); the slight decrease in plasma insulin observed between 2 and 4 days was not statistically significant.

The effects of insulin infusion, at the rate of $0.4 \mathrm{U} / \mathrm{h}$, on the ability of liver subcellular fractions to bind insulin are depicted in Fig. 1 (lower panels). During the first day, insulin-induced hyperinsulinemia was accompanied by a 2 to 4 -fold increase in the ability of Golgi-endosomal fractions to bind insulin, which was detectable at $3 \mathrm{~h}$ and affected to a greater extent GEI (4-fold increase) than GEi and GEh (2-fold increase). Concomitantly, there was a 2-fold decrease in the ability of plasma membranes to bind insulin. After 1 day, the changes in insulin binding activities in GEI, GEh and plasma membranes were maintained, but the enhancement of binding activity in GEi became progressively less marked. Throughout the study, insulin binding to the total particulate fraction remained unchanged. Whether the changes in insulin binding described result from changes in receptor affinity or capacity has not been determined.
Golgi-endosomal fractions $(\mathrm{GEi}$ and GEh) of insulin-infused rats displayed an increase of insulin content relative to corresponding fractions of saline-infused animals (Table I). This increase was more pronounced during the first day of study

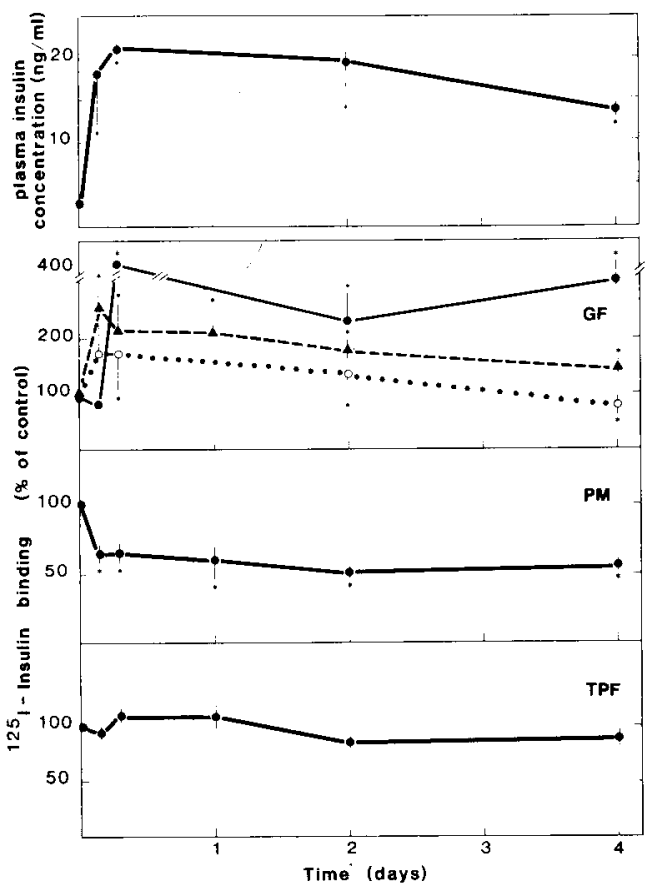

Fig. 1. Plasma insulin concentration (upper panel) and specific insulin binding activities (lower panels) in light (๑), intermediate (o) and heavy ( $\Delta$ ) Golgi-endosomal fractions (GF), in plasma membranes (PM) and in the total particulate fraction (TPF) from rats infused with insulin at the rate of $0.4 \mathrm{U} / \mathrm{h}$, as a function of time of infusion. Plasma insulin concentration in salineinfused rats was $2.76 \pm 0.25 \mathrm{ng} / \mathrm{ml}$ (mean \pm S.E.M., 18 determinations) and did not vary throughout infusion. Insulin binding activities in subcellular fractions of saline injected rats, expressed as cpm/ug of protein, were, respectively, $28 \pm 4,115 \pm 16$ and $160 \pm 8$ for light, intermediate and heavy Golgi-endosomal fractions, $258 \pm$ 10 for plasma membranes, and $29 \pm 1$ for the total particulate fraction (mean \pm S.E.M., 12-20 determinations). ${ }^{*} P<0.05$ vs control. 
(10-15-fold over control), than at later times (less than 5 -fold over control).

In rats infused by insulin at the rate of $0.2 \mathrm{U} / \mathrm{h}$, plasma insulin concentration was increased by only 2 to 3 -fold, and the changes in insulin binding activities of liver subcellular fractions at 2 and 4 days dif- fered from those observed in rats infused with the higher dose (Table II). First, there was little (10-15\%) decrease in the binding activity of plasma membranes and second, binding activity was decreased by $40-50 \%$ in GEl and GEi and was unchanged or increased only slightly in GEh. However, the insulin content of GEh did not differ from

Table I. Concentration of immununoreactive insulin in acid extracts fo intermediate and heavy Golgiendomosal fractions of rats infused with insulin at the rate of $0.4 \mathrm{U} / \mathrm{h}$, as a function of time of infusion. Results are the mean \pm S.E.M. of several determinations, the number of which is indicated in parentheses.

\section{Experimental groups and time of sacrifice \\ Immunoreactive insulin ( $p g / m g$ protein) Intermediate Golgi-endosomal fraction Heavy Golgi-endosomal fractions}

\begin{tabular}{|c|c|c|}
\hline Saline-injected rats * & $\begin{array}{c}606 \pm 80 \\
(10)\end{array}$ & $\begin{array}{c}433 \pm 42 \\
(14)\end{array}$ \\
\hline \multicolumn{3}{|l|}{ Insulin infused rats } \\
\hline 3 h 30 & $\begin{array}{c}5862 \pm 1472 \\
(4)\end{array}$ & $\begin{array}{c}3977 \pm 128 \\
(4)\end{array}$ \\
\hline $7 \mathrm{~h}$ & $\begin{array}{c}9527 \pm 11 \\
(2)\end{array}$ & $\begin{array}{c}6881 \pm 2150 \\
\text { (2) }\end{array}$ \\
\hline $24 \mathrm{~h}$ & $\begin{array}{c}5442 \pm 1992 \\
\text { (3) }\end{array}$ & $\begin{array}{c}4150 \pm 1772 \\
\text { (3) }\end{array}$ \\
\hline $48 \mathrm{~h}$ & $\begin{array}{c}869 \pm 45 \\
(5)\end{array}$ & $\begin{array}{c}1037 \pm 69 \\
(5)\end{array}$ \\
\hline $96 \mathrm{~h}$ & $\begin{array}{c}1727 \pm 346 \\
(4)\end{array}$ & $\begin{array}{c}1994 \pm 357 \\
(4)\end{array}$ \\
\hline
\end{tabular}

* All times confounded

Table II. Plasma insulin concentration and specific insulin binding activity of liver subcellular fractions of rats infused with insulin at the dose of $0.2 \mathrm{U} / \mathrm{h}$ during 2 or 4 days. Results are the mean \pm S.E.M. of 3 determinations. Plasma insulin concentration and insulin binding to subcellular fractions from salineinjected rats were similar to those indicated in legend to Fig. 1.

\begin{tabular}{lcrrrr}
\hline Time & Plasma insulin & \multicolumn{4}{c}{ Insulin binding activity (\%of control) } \\
\hline & $(\mathrm{ng} / \mathrm{ml})$ & GEi & GEh & PM & TPF \\
& & & & & \\
2 days & $6.3 \pm 2.5$ & $32 \pm 1$ & $95 \pm 28$ & $86 \pm 6$ & $99 \pm 8$ \\
4 days & $5.6 \pm 2.2$ & $60 \pm 28$ & $129 \pm 35$ & $87 \pm 9$ & $87 \pm 2$ \\
\hline
\end{tabular}

GEi : intermediate Golgi-endosomal fraction; GEh : heavy Golgi-endosomal fraction; PM : plasma membranes; TPF : total particulate fraction 
that observed with the higher dose (results not shown).

\section{DISCUSSION}

These studies show that, in rats infused with the high dose of insulin, the early changes in the subcellular distribution of insulin receptors and in the insulin content of Golgi-endosomal fractions are similar to those reported after a bolus injection of insulin (Desbuquois et al., 1982). After one day, however, the increase in the amount of receptor and ligand associated with Golgi-endosomal fractions became progressively less marked, despite the persistence of the hyperinsulinemia. On the other hand, in rats infused with the low dose of insulin, hormone binding activity was little decreased in plasma membranes and was decreased or unaffected in Golgiendosomal fractions, although the insulin content of the latter was also increased. These findings suggest that, while enhanced receptor endocytosis probably occurs in both experimental groups, only with the high dose of insulin and at an early stage of the hyperinsulinemia does this mechanism account for the changes in receptor distribution.

The decrease in the ability of liver plasma membranes to bind insulin, which occurs in rats infused with the high dose of insulin, is comparable to that reported by Vigneri et al. (1978) in rats rendered hyperinsulinemic for $24 \mathrm{~h}$ by two insulin injections. However, at variance with these investigators, who reported that insulin binding activity was also decreased in endoplasmic reticulum fractions, we found that insulin binding activity in the microsomal fraction was unchanged or increased slightly (experiments not shown).
The changes in the insulin binding activity of liver subcellular fractions, observed in rats infused with the low dose of insulin, are reminiscent of those described in 4week old genetically obese Zucker rats in which plasma insulin concentration is elevated to the same extent. Indeed, in these animals, the only change detectable was a decrease in insulin binding activity of Golgi endosomal fractions, along with an increased or unchanged insulin content in these fractions. These results further support the concept that, in both experimental models, enhanced receptor endocytosis is not the major mechanism involved in insulin receptor regulation.

Because insulin at a high dose induces a decrease in blood glucose concentration, the possibility that counter-regulatory hormones contribute to the changes in insulin binding activity must be considered. Indeed, both glucagon and epinephrin have been shown to cause a decrease in insulin binding to intact, isolated adipocytes (Pessin et al., 1983; Yamauchi \& Hashizume, 1986). It is not known, however, whether these hormones exert similar effects in isolated hepatocytes. In addition, although glucagon has been shown to induce endocytosis of the insulin receptor in liver in vivo (López \& Desbuquois, 1983), this is an indirect effect which is mediated by endogenously released insulin.

Although differing with respect to several biochemical and morphological criteria, the three Golgi-endosomal fractions, as prepared in this work, are known to consist of both Golgi elements and endosomes (Bergeron et al., 1985).

On the assumption that these organelles represent the main sites of localization of newly synthesized and internalized receptors, respectively, the increase in the insulin receptor number in Golgiendosomal fractions of hyperinsulinemic rats might reflect either enhanced receptor 
synthesis or enhanced receptor endocytosis. While the experimental evidence described here and in earlier works (Desbuquois et al., 1982; López \& Desbuquois, 1983) favours the latter mechanism, additional studies must be performed to rule out the former.

\section{ACKNOWLEDGMENTS}

We thank Ms. H. Burlet and Ms. A. Dupuis for their excellent technical assistance.

\section{REFERENCES}

Benelli C., López S., Desbuquois B. \& Achagiotis C. (1988) Changes in low Km cAMP phosphodiesterase activity in liver Golgi fractions from hyper- and hypoinsulinemic rats. Diabetes 37, 717-722

Bergeron J.J.M., Cruz J., Khan M.N. \& Posner B.I. (1985) Uptake of insulin and other ligands into receptor-rich endocytic components of target cells : the endosomal apparatus. Ann. Rev. Physiol. 47, 383-403

Clark J.B. \& Clark C.M. (1982) Age-related changes in insulin receptor regulation in liver membranes from Zucker rats. Endocrinology 117, 964-969

Desbuquois B., López S. \& Burlet H. (1982) Ligand-induced translocation of insulin receptors in intact rat liver. J. Biol. Chem. 257, 1085210860

Kahn C.R., Neville D.M. \& Roth J. (1973) Insulin-receptor interaction in the obese- hytperglycemic mouse. A model of insulin resistance. J. Biol. Chem. 248, 244-250

Le Marchand Y., Freychet P. \& Jeanrenaud B. (1978) Longitudinal study on the establishment of insulin resistance in hypothalamic obese mice. Endocrinology 102, 74-85

López S. \& Desbuquois B. (1983) Changes in the subcellular distribution of insulin receptors in rat liver induced by acute endogenous hyperinsulinemia. Endocrinology 113, 783-789

López S. \& Desbuquois B. (1987) Insulin-related changes in the subcellular distribution of insulin receptors in intact rat liver : effects of hypoinsulinemia induced by diazoxide, somatostatin and xylazine. Endocrinology 120, 1695-1702

López S., Desbuquois B., Postel-Vinay M.C., Benelli C. \& Lavau M. (1988) Insulin-dependent changes in the subcellular distribution of liver insulin receptors in obese Zucker rats. Diabetologia 31, 922-927

Pessin J.E., Gitomer W., Oka Y., Oppenheimer C.L. \& Czech M.P. (1983) $\beta$-Adrenergic regulation of insulin and epidermal growth factor receptors in rat adipocytes. J. Biol. Chem. 258, 7386-7394

Pezzino V., Vigneri R., Pliam N.B. \& Goldfine I.D. (1980) Rapid regulation of plasma membrane insulin receptors. Diabetologia 19, 211215

Posner B.I., Raquidan D., Josefsberg Z.S. \& Bergeron J.J.M. (1978) Different regulation of insulin receptors in intracellular (Golgi) and plasma membranes from livers of obese and lean mice. Proc. Natl. Acad. Sci. USA 75, 3302-3306

Vigneri R., Pliam N.B., Cohen D.C., Pezzino V., Wong K.Y. \& Goldfine I.D. (1978) In vivo regulation of cell surface and intracellular insulin binding sites by insulin. J. Biol. Chem. 253, 81928197

Yamauchi K.J. \& Hashizume K. (1986) Glucagon alter insulin binding to isolated rat epididymal adipocytes : possible role of adenosine $3{ }^{\prime} 5^{\prime}$ monophosphate in modification of insulin action. Endocrinology 119, 218-223 